DESERVING DESIRE 



\section{DESERVING DESIRE}

Women's Stories of Sexual Evolution

BETH MONTEMURRO

RUTGERS UNIVERSITY PRESS

New Brunswick, New Jersey, and London 
Library of Congress Cataloging-in-Publication Data

Montemurro, Beth, 1972-

Deserving desire : women's stories of sexual evolution / Beth Montemurro.

pages $\mathrm{cm}$

Includes bibliographical references and index.

ISBN 978-0-8135-7022-8 (hardcover : alk. paper) - ISBN 978-0-8135-6439-5

(pbk. : alk. paper) - ISBN 978-0-8135-7024-2 (e-book)

1. Women-Sexual behavior. 2. Women-Psychology. 3. Self-acceptance. I. Title.

HQ29.M653 2014

$306.7082-\mathrm{dc} 23 \quad 2013046604$

A British Cataloging-in-Publication record for this book is available from the British Library.

Portions of Chapters 4 and 5 appeared in the article "Getting Married, Breaking Up, and Making Up for Lost Time: Relationship Transitions as Turning Points in Women's Sexuality," Journal of Contemporary Ethnography, 43(1) (February 2014): 63-93.

Copyright (C) 2014 by Beth Montemurro

All rights reserved

No part of this book may be reproduced or utilized in any form or by any means, electronic or mechanical, or by any information storage and retrieval system, without written permission from the publisher. Please contact Rutgers University Press, 106 Somerset Street, New Brunswick, NJ 08901. The only exception to this prohibition is "fair use" as defined by U.S. copyright law.

Visit our website: http://rutgerspress.rutgers.edu

Manufactured in the United States of America 
For Madison, "I felt you in my legs before I ever met you." (Tegan and Sara, "Nineteen") 
